\title{
ARÇURA/ŞÜRÄLE: MYTHICAL SPIRITS OF THE VOLGA-URAL FORESTS
}

\author{
RUSTEM SULTEEV \\ 49B Cowper Gardens, Southgate, \\ London N14 4NS, UK \\ e-mail: rustemsulteev@gmail.com
}

Folk beliefs, which have their source in history, culture and geography, are among the most significant factors determining the identity and characteristic features of a people. In Tatar and Chuvash folk literature myths about mythological beings are often stories written in prose, describing supernatural creatures and spirits. These stories describe "encounters" between humans on the one hand and various mythological creatures, on the other. Among these Arçura/Şüräle is a Forest Spirit which has a very significant role in folk narratives of not only the Tatars and the Chuvash, but widely in the folk culture of other Volga-Ural peoples. These mythological beliefs help people of the VolgaUral region perceive themselves as a part of the universe. In this paper, the etymology of the word Arçura/Şüräle is investigated; then its characteristics and its comparison with some other neighbouring Volga-Ural Finno-Ugrian and shamanic Turkic-Mongol spirits are examined.

Key words: mythology, Forest Spirit, Şüräle, Arçura, Tatar folk narratives, Chuvash folk narratives.

\section{Introduction}

Folk beliefs, which have their source in history, culture, and geography, are among the most significant factors determining the identity and characteristics of a people. These beliefs which carry traces of paganism, above all show peoples' ways of thinking, traditional ties with the environment and nature in early ages, whilst each ethnic group has its own type of myths and beliefs related to mythical creatures. This also concerns mythical creatures which were in charge of trees, plants, animals and birds in forests. In the early ages forests and woods were imbued with a certain degree of mystery, undoubtedly intensified by the deep and solemn shadows which lay hidden within their depths. They were believed to be peopled with crowds of strange beings endowed with superhuman powers and characters, although partaking of human form. These various beings were known under several names, and had different natures. 
Some possessed benevolent qualities, seeking to do good to mankind, while others were of a malevolent disposition, forever trying to work harm. Among the former may be mentioned the Fairies and other genial spirits, and the latter class comprised Demons of every description (Porteous 1928, p. 84). As an example we can mention Waldleute of German mythology, Pan and the Dryads of Greece and Italy. Estonian folklore has various elements of forest mythology like Eksitaja, Metsavana and Travelling forests. From Chuvash mythology we can mention Ovda, Obyda, Upäte. In Tatar mythology numerous Forest Spirits exist, some of them are identical but under different names, like Äbädä, Qarurman Babay, Urman Hucasl, Yış Keşe, Pitsen, A ̆gaç Keşe, Şeki, Urman Pärie, Urman Sarığı, Yarımtıq Urman Iyäse, and his/her daughter: Urman Klzl (also called Tayçulpan), etc. However, in Tatar folklore none of them has the level of popularity as Şüräle which in Chuvash folklore is known as Arçuri/Arçura, although both characters are practically the same. "Among the Tatars and Chuvashes the Forest Spirit has already received a strictly defined appearance, which proves a more developed, more stable plane of thought. Here the Forest Monster, corresponding to Russian spirits, chiefly an evil being, which is seldom worshipped. In this respect is different from the Forest Spirits of the most northern primeval forests of Siberia" (Holmberg 1927, p. 467). The Forest Spirit has an important role in the folk narratives of the Tatars, Chuvash and other ethnic groups of the Volga-Ural region.

"An extremely wide-spread belief is that the Forest Spirit, having bewildered human beings and enticed them into its power, tickles, dances, or smothers them to death. The explanation of this curious idea is to be found in the psychic state that overwhelms the individual, when lost in the forest, and, in desperation, he sees no chance of ever finding his way out" (Holmberg 1927, p. 190). From a psychological perspective this can be an explanation of the wide-spread belief in Arçura and Şüräle, and that they are mostly seen in spring and autumn, during sunrise or sunset, i.e. when all objects become dim, gloomy or dark. Also, Arçura/Şüräle is a shapeshifting woodland spirit who protects wild animals and forests. Their role is to protect the animals and birds in the forest and tell them when to migrate.

\section{The Volga-Ural Area}

The Bulgar tribes migrated from the south to the Volga-Kama and Ural region in the 7th-9th centuries, and founded their state in the 10th century which existed until 1236 when Volga Bulgaria was conquered by the Mongols. Both modern Kazan Tatars and Chuvash, and partly Bashkirs, are descendants of the Volga Bulgars, so a large part of the region's population included Turkic groups, while another part comprised native Finnic tribes. Through the Volga Bulgars, who accepted Islam in 921, Islamic civilisation made its way and spread in some measure also among the Volga Finns. Nevertheless, the ancient pagan beliefs of the Bulgars have also left deep traces, particularly as regards the religious concepts and customs of the Volga Finns.

After the Mongol conquest in 1236 Volga Bulgaria became a part of the Golden Horde, westernmost appenage of the Mongol Empire. Under the influence of Bulgar 
culture, more and more nomadic Mongols and Kipchaks were converted to Islam, and mingled with the local population. Thus Mongol shamanic traditions also found their way to the folklore of the Volga-Ural peoples which form the second "pagan" layer of Volga-Ural mythology.

In the 1440s, all lands inhabited by Volga Bulgar population were included into the Khanate of Kazan, ruled by a Turkicised offspring of Chingisid khans. From then onward the Kazan Khanate became practically independent from other parts of the one-time Golden Horde. The Khanate also included Mari and Chuvash lands, while the rulers of the territories of Bashkirs, Udmurts and Mordvins in the Volga-Ural region, were considered vassals of Kazan. These were the peoples that traditionally had been under the economic and cultural influence of Volga Bulgaria. At a later period, hand in hand with Russian colonisation, Russian folk-belief also penetrated everywhere. Therefore, Volga-Ural peoples have been subject to several heterogeneous civilising influences, which are clearly reflected, among other evidences, by their language and mythology.

The term 'Volga-Ural' is often used to designate six autonomous regions of Russia: Bashkortostan, Chuvashia, Mari El, Mordovia, Tatarstan, Udmurtia, especially in Tatar-language literature or in the context of minority languages. The Volga-Ural region is settled by a mixed population of Turkic, Finno-Ugric and Slavic ethnic groups whose pagan, Christian and Muslim cultural backgrounds created a great variety and wide range of literary and folklore traditions. The Volga-Ural peoples not only lived side by side, but also intermarried, so that in due course a new and distinct Volga-Ural culture developed. But one must be careful and, by the same token, not to assume that Volga-Ural paganism was a single, homogeneous belief structure. On the other hand, we can safely talk about a common world-view or even mythology. However, it seems that, Volga-Ural Forest Spirits have some similarities with their North European counterparts, perhaps because of a Finno-Ugrian factor as Northern Europe was also inhabited by Finno-Ugrian peoples (Finn, Karels, Estonians etc.), who played a cultural bridge function between these two geographical areas of the world.

\section{Problems concerning the Research of Arçura/Şüräle}

In the Volga-Ural region, especially in Tatarstan, different types of work have already been written and a large set of stories about Şüräle collected. This topic was also dealt with by the German scholar, Johannes Benzing. He presented a poem of the great Tatar poet Abdulla Tukay titled Şüräle, then researched the concept of Tukay's Forest Spirit, as to whether it was the same as the Chuvash Forest Spirit Upäte-Arçura (Benzing 1947, pp. 73-85). According to Benzing, the Chuvash word şävär 'sharp' developed into the form şür + e.g. şüreke: "conical" and was connected with the Chuvash word alä 'hand', which originates from an older form old Turkic älig, so the word Şüräle would mean 'pointed hand' (Benzing 1947, pp. 80-81). But in this etymology there is no trace of historical argumentation, no parallels for demonstration of the function of -eke in šüreke. Furthermore, it is unfortunate that Benzing drew solely on 
the works of the Hungarian Turkologist Gy. Mészáros and the Chuvash researcher N. I. Ashmarin (Benzing 1947, pp. 80-85). According to Benzing, "the word is a foreign one belonging to the series which proves the influence of the Volga-Bulgarian and Chuvash population upon the Tatars" (Benzing 1947, p. 80). But he paid insufficient attention to the fact that the Volga Tatars, as well as the Chuvash, are descendants of the Volga Bulgars and referred to them as if they were two completely distinct ethnic groups. The lifestyle as well as the shamanic traditions of the Volga Tatars and the Chuvash have many similarities because they both have a common origin in the Volga-Ural region.

W. Radloff in his Wörterbuch gives some information about Şüräle like 'a wooden man (a creature, who has three fingers, lives in the forests and attacks people or kills them by tickling)' (Radloff 1960, p. 1110). Sü̈räle is also known among the Bashkirs. As mentioned in Rudenko's book, Trans-Uralic Bashkirs used to call this mythological creature Şüräle, north western Bashkirs call it Yarımtıq (RudenkoKurban 2001, p. 381). Süräle is also used as a geographical name in the north of Bashkortostan. There is information about the existence of a mountain, a rock and a village called Şüräle at the beginning of the 20th century (Ğiyl'manov 1999, p. 71). In addition, this mythological character exists even among the Kazakhs, they call it Sorel, although geographically they live far from the Chuvash areas.

According to many Tatar researchers the origin of the word Şüräle is şerr/şer ("badness", "harm" in Arabic) + el ("hand" in Turkic) + le (suffix), i.e. "evil-doer", "scary handed creature" (Zamaletdinov 1979, p. 117). Even nowadays the verb şürläw "to be afraid, to be scared" is used by Tatars. The Tatar researcher Ğ. Ğyl'manov thinks that the name of Chuvash Arçura/Arçuri/Arsuri is also derived from the root şür-, şürläw in relation to the appearance and deeds of the creature (Ğiyl'manov 1996, p. 153). However, it would be wrong to explain the etymology of a pre-Islamic mythological creature with an Arabic word, as such words like şerr/şer/şär started spreading in the Volga-Ural area only with Islam. Likewise, this derivation lacks any historical phonetic and morphological proof to explain the phonetic and structural change, so it can be disregarded as the etymology of Şüräle.

Benzing, in his above-mentioned article, claimed that Süräle is a mythological creature of Chuvash origin and the Tatars just copied it from them. However, as will be seen, this mythological creature can be found not only in Chuvash and Tatar mythology. There are many analogies in other Volga-Ural and Altaic mythologies. While concepts of the 'folk' and 'folk culture' were important in creating romantic-nationalistic constructions of the nation in the 19th-20th centuries, and these ideas still retain considerable power for many individuals and peoples, scholarship in the past fifty years has tended to be critical of such essentialist notions. As a result of that, so far the word Arçura/Şüräle has no real etymology as the listed explanations are only ideas, hypotheses, but not linguistically well-based etymologies.

It is a well-known fact that nations often resorted to folklore when they intended to fulfil any spiritual need. For instance, interest in folklore in Turkey began in the second half of the 19th century, when the need was felt to forge a national language which could be understood by the majority (Başgöz 1972, p. 162). According to İlhan 
Başgöz, this limited aim, however, turned into a full cultural movement to discover the forgotten culture of the Turkish nation when the nationalistic movement rejected the main cultural traits of the Ottoman Empire, in language, art and politics (Başgöz 1972, p. 176).

Nationalism, which had shaken Europe in the 19th century and later Turkey after the First World War, did not become an important force in the former USSR republics until the time of perestroika, although in the past it did have a role during the first few decades of the 19th century and exerted significant influence on that region. With most former USSR ethnic groups, among them peoples of the Volga-Ural region, interest in folklore began grow after perestroika, in the last decade of the 20th century, when the need was felt to revive national languages, which were on the verge of disappearance. Although equation of folk beliefs with a single 'nation' has once been much in vogue in folklore studies, we must not forget that myths have no beginning or evident point of origin.

Nevertheless, the question that should be asked is whether it will ever be possible to sketch a collective picture of Arçura/Şüräle and draw relevant comparisons with related concepts. Arçura/Şüräle is a subset of mythologies, but many writers relying on secondary (or even tertiary) sources are unaware of this fact and refer to them as if they were distinct or separate mythologies. So, Arçura/Şüräle (like similar mythological creatures of Volga-Ural, Obyda, Yarımtıq, Alid/Nyulesmurt/Palesmurt, Viryava, Tarğllttş/Targeldesh) is a common and popular mythical character which has been preserved in Volga-Ural folk narratives in nuances. It would be sensible to research Arçura/Şüräle adjoined with ancient beliefs of different ethnic groups of VolgaUral as many of them are in some way connected. Ovda is an evil Forest Spirit who has descended from the Chuvash to the Volga Finns (Holmberg 1927, p. 183). According to Holmberg, «Tatar influence is perceptible in the Southern Votiak (Udmurt-RS) area. As appears already from the name, the evil Şüräle is a loan from foreign sources. The "Half-man", who seems to have been known also among the Ostiaks (KhantyRS), corresponds to the Chuvash Ar zori (Arçura), which has the same meaning, and the "Cowfooted man" to the Tatar Syir-ajak ("Cow-foot")» (Holmberg 1927, p. 182). However, it would be more appropriate to say that shamanic Bulgar mythology was influential in all over the Volga-Ural area.

\section{Shamanic Traditions about Çors and the Undead}

In shamanic tradition all humans and animals possess more than one soul and there are many different types of spirits in the sky and in nature; some are very strong and cannot be mastered by shamans; others are relatively easy to control. They can be called for assistance during shaman rituals.

We can see this for example in the Mongolian Shaman tradition. The earth is the home of a great variety of spirits, including çötgör, Otsoor, Ongon, Burkhan and Gazriin Ezen (for more information on these notions, see Sarangerel 2000; 2001). Çötgör spirits (in Mongolian and its sub-groups within the greater Mongolian languages 
pronounced as Çotgor, Çutgur, Çutkur, Çetger, Çetker, Çidkür, Çutker, Südkür, Sötkör, Şudher, Şütgör, Şütger, Cidkür) frequently bring along disease, mental illness or confusion. Some çötgörs are destructive spirits, usually human suns souls that have failed to return to the lower world after death. They are the common cause of disease (Sarangerel 2001, p. 244). Suns is the human soul that originates in the lower world. It can reincarnate anywhere and does not follow lineages (Sarangerel 2001, p. 254). Çötgör spirits in many Turkic languages are also known as kut/qot or Abaass. In Tatar mythology Abaast/Albast turned into an individual creature, which brought nightmares and could also take the shape of a tiny goat and sit on men's faces. The word kut/qot signifies the soul of both human beings and natural objects. It is used for expressing the fact that a field has lost its fertility. Also, expressing fear: qot očuw "qot flew away". Similarly, the kut of a dwelling-place may depart, taking with it the feeling of homeliness. In cases like this last one, kut is often translated as "happiness", "comfort", "abundance", "health", "homeliness", etc. "A word with a similar meaning in the Tatar language is sür ("appearance", "beauty", "comfort”, "power", "soul”), used when speaking of the human soul, the haunting spirit of the dead, the health of cattle, the power of an army, the nourishing properties of bread, etc. Thus, for example, it is said that "its sür has departed." A soul of this description is believed to be animate and to govern all the phenomena of nature and its parts, and thus a conception arises that these invisible souls, to use the words of M.A. Castrén, are "in respect of all visible nature, in a position of power resembling that of a master towards his property" (Holmberg 1927, p. 463). In the modern Tatar language the word sür can be found in the expression sömsere koylluw "to lose the spirit of courage and self-esteem". The word sömser itself, which means "one of the phenomena of the soul, a formidable soul; the spirit of courage and self-esteem" is considered an archaic word. It seems to have two components of the soul: söm/sön/sün/sun ("çötgör are suns spirits of dead people") + ser/sür. However, the word sür preserved as çor which has some other variations like çer, çur, çor, çar, çura, çora.

Similarly, in Turkic mythology Çors are spiritual creatures, mentioned in preIslamic texts and oral tradition, who inhabit an unseen world in dimensions beyond the visible universe of humans. Folk narratives mention that the Çors are made of fire, but also physical in nature, being able to interact physically with people and objects and likewise be acted upon. Like human beings, a Çor can also be good (Aq-çor/Aqçora "White-Çor"), evil (Qara-çor/Qara-çora "Black-Çor"), or neutrally benevolent, hence it has freewill like humans and unlike angels.

Çors are independent, but they may also be connected to a particular place. The fact of their living in places under trees, dark out-of-the-way places, ruins, destoryed houses, shores, under bridges which are close to natural surroundings and features such as the mountains, forested areas and the like, gave rise to a notion of their connection with enchanted and obscure powers. They are afraid of iron. The saying Bismillah "In the name of God", will take them away, since they flee away when hearing Bismillah, an invocation derived from Islam. Actually, with the embracement of Islam Çor was replaced by Jinn: a being or spirit who can assume human or animal form and influence man by supernatural powers. 
In Anatolia it is known as Çorabaş. The expressions like Çor vurması, çor çarpması, çor değmesi "being possessed" refer to diseases related to Jinns (mostly, paralysis of mouth, partial paralysis or losing their mind). Sometimes Çor means mental illness. It is important not to mix this Çor with Arabic Şerr, despite their similarity (Karakurt 2012, p. 251).

Çötgör means devil in Mongolian. It likes playing games. Whoever accepts his offer to be tickled, he thus tickles that person to death (Karakurt 2012, p. 251). This is exactly what the Volga-Ural Arçura/Şüräle does. It is significant that in the expressions Çötgör oroh "to be possessed by a demon", Çötgör algad "the devil take it", the second components oroh and algad display signs of the same linguistic origin or roots. Cf. Mongol Çötgör oroh, in Turkish Çor vurma, in Tatar Cen oruw; in Mongol Çötgör algad, in Tatar Cen alğırı.

Çertegri covers the concept of Satan in Turkic and Altaic folk beliefs. They are the most dangerous and evil among all Çors and can cause irreversible damage to people as they have terrible and powerful capabilities.

In Yakut there is a word Çuğort which means "evil spirit". According to research, the word Çor (another version of it is Çert) in Turkic languages has an analogue with Chort in neighbouring Russian and Slavic folklore and is considered to be a demon of total evil, with horns, hoofs, skinny tail, and a pig-face in Slavic mythology (demonology) (Karakurt 2012, p. 251).

In the Russian language one can observe traces of the Turco-Mongolian shamanic tradition, especially in curses, e.g. tysiacha chertei meaning "thousands of demons", chort poberi "overtaken by the demon", chort poputal "mixed up by the demon", $k$ chertiam "go to hell", and many others.

The Russian word chur is also related to this word. It is used in different situations with several meanings: (1) "whoop which protects against evil forces", (2) "whoop which forbids touching on something, to cross beyond some boundary".

The Russian expression chur menia, chur which is used in children's games when a player announcing that he or she is on the side and cannot be touched, also derives from that belief. It seems that in these expressions chur is used in the meaning "border, limit, measure, persuasion, ban, law", which corroborates our theory. Also, the ancient Slavic deity Shchur may go back to Çor. Belarusians say that every host has its chur, the creature that protects the boundaries of its agrarian lands which is a kind of an analogue of Biçura in Tatar mythology.

There are many other shamanist traditions about corpses coming back to life because they have been taken over by a foreign spirit, such as a nature stray suns soul, or a nature spirit, a burhan or a çötgör. Some of the undead are said to be almost normal, while others are extremely abnormal and dangerous to human beings.

The first type of undead entity is the bug or bong. The majority of bong are female and are capable of having children if they marry or have sex. Most bongs live out in the forest, surviving on badger meat and living in danger of being killed by dogs and wolves, animals that often eat corpses. Bongs have long hair which generally covers the third eye that they all have in their forehead. One Buryat legend tells 
of a very beautiful bong that married a prince and was executed when her true identity was discovered. Her revenge was giving tobacco to the world.

A much more dangerous creature is the ibagan, a corpse inhabited by a çötgör. Ibagans have long hair covering their bodies and a vicious disposition. Their mere touch is fatal for human beings. The only way to kill ibagan is with an axe, afterwards the creature must be burned with all of its victims (Sarangerel 2000, chapter 3).

\section{Biçura}

There are two different kinds of çors: Arçura and Biçura. The latter that lives in homes and basements, is a household spirit in Tatar folklore. Traditionally, every house is said to have a Biçura. The other one, Arçura wanders in forests (Karakurt 2012, p. 251).

It is important to mention that the word Çor existed in the Volga-Ural region generally as Çur and/or Çura as in Arçura and Biçura. From now onwards, we will use Çura as well as Çor when referring to Volga-Ural mythology.

In order to comprehend Arçura we need to interpret its analogue Biçura. VolgaUral Tatar folklore says that Biçura can take on the appearance of cats or dogs. Other stories either give them completely monstrous appearance, or none at all. The actions performed by a Biçura vaguely resemble those of poltergeists and are not necessarily harmful. It has also been said that a Biçura could harass horses in the stable overnight, as well as steal the grain of a neighbour to feed his own horses. In this regard, it has similarities with The Red Mother in Mongol mythology, who is a human soul who died with unnatural death, as same as Arçura/Şüräle likes stealing and riding a horse.

If Biçura becomes unhappy, it plays nasty tricks on the members of the household. Those include moving and rattling small objects, breaking dishes, leaving muddy little footprints, causing the walls of a house to creak, banging on pots and moaning. If the family can determine the cause of their Biçuras' discontent, they can rectify the situation and return things to normal. More often than not, however, families live in harmony with the spirits, and no problems arise.

If it is unbearable, the only way to get rid of Biçura is bringing a bear and the spirit will run away. As is well known the bear is one of the two great shaman animals (the second one is eagle). The bear which is associated with the east, is a conductor of souls on their way to the lower world after death (Sarangerel 2001, p. 243).

There are many indications that this mythological creature is female. When a Biçura inhabits a house, she lives behind the stove or in the cellar. When home builders wanted to do something harmful to the person buying the house, they would bring in a Biçura. Once inside, it is difficult to compell her to leave. When the house is in order, Biçura looks after the chickens and housework. If not, she whistles, breaks dishes and makes noises at night. She also comes out at night to spin. Biçura also exists among the Volga Finns where "generally speaking, is a kindly and useful spirit, protecting the inhabitants of the house from strange spirits and in every way looking 
after the interests of the house. He may even at times take part in the household duties" (Holmberg 1927, p. 159).

Among Bashkirs there is a belief that they used to live in the meadows of dense forests. They help those people who took them to live together and sheltered them by bringing money and help them to become rich. In Bashkir mythology it is an evil female spirit in red. Biçuras are able to give someone unprecedented mastery of a skill.

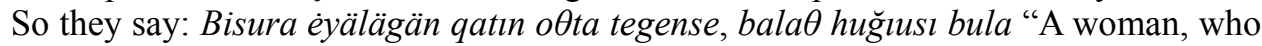
is possessed by Biçura is a good skilled seamstress, a carpet maker". Also, among some Tatar ethnic groups this mythological creature is presented as a short woman with an old hat on her head. Biçuras would pull hair to warn a woman of danger from an abusive man. Also, Biçuras like playing with men, especially with single men and widowed ones: suffocating them, waking them up by sneezing or throwing different things on them. Interestingly, Biçura wears red dresses (Karakurt 2012, p. 173).

\section{The Etymology of Biçura, Arçura/Şüräle}

The word Arçura exists in different phonetic variants: Arçuray, Arçuri, Arsuri, Arsüri, Arzurri, Arzyuri, Arçurl, Ar-duri, Ar-sori, Ar-Durri, Ar-Sorri, Ar-Çuri, Ar-Çor, ArDuri which can be explained by vowel and consonant changes of the Turkic languages. From now on, to avoid confusion we will use only the commonest form, Arçura. According to Benzing (1947, p. 81) the word Arçura means "half-man". Also, Enderov (1984, p. 52) writes that "it has two components: Ar 'human, man' and Surri 'half', i.e. 'semi-human'”.

However, it is obvious that the word Arçura is made up of ar +çura. Chuvash ar (<Turkic är) means "man, male" equivalent to $i r$ in modern Tatar. "In Mongolian and Siberian, as well as in other traditions, the essence of shamanic work is developing a relationship with the spirit world. The most important relationship of all is that between the shaman and his helper spirits, a 'spirit family' that empowers and protects him during his work" (Sarangerel 2001, pp. IX-X). So, we can regard Arçura and Biçura as members of a family or community of spirits (çura). Hence, another meaning of the word ar, "assistant, warrior, helper", can also be considered here. As for Biçura we can presume that it is made up of the Turkic words bi(y) "master, lord" and çura. As a result, in the çura hierarchy Biçura's social status/rank is higher. The reason for that is as below: "Soul and spirit have different meanings in shamanism. For example, a living tree has its own soul, but a forest as a whole and other natural resources have their own special spirit. If someone cuts down the tree then it dies, but if someone builds a wooden house then house's spirit will always exist because many trees were killed in order to build it. If people use trees wastefully or start wildfires, their spirits get angry and natural disasters such as floods and snowstorms will ensue. So, the main difference is that soul belongs to a single entity such as a person, a planet or animal, while land and water spirits protect an area or group of entities" (Kerrigan 1998, p. 25). That is the reason why the Biçura is higher than the Arçura: the Biçura is "the master/lord (bi) of souls of many trees". 
As for Şüräle it may derive from çura $+u l$ "son of çura". The alteration $c ̧ \sim s ̧$ is typical for many old and modern Turkic languages. Even now /ç/ in Tatar literary language sounds close to the fricative consonant /ş/, so Çura $\sim$ Şura is a typical transition. Similarly, in Tatar there are words which have paronyms: for example şaltıratuw, şlltıratuw çıltıratuw, çelterätüw "to ring". Subsequently, Çur/Çura + ulı may have had paronym(s): Şur/Şura + ull the palatal variants of which could have sounded Şür/Şürä $+u l$. Another possibility is that Çura/Şura was added a derivational suffix (Çurall-Şural). The denominal suffix $+l X$ in Turkic languages means "originating from, furnished with, place of". This suffix gives the sense of belonging to something or somewhere. It is especially frequently used with place names: Qırım $\rightarrow$ Qırıml "Crimean", Osman $\rightarrow$ Osmanlı "Ottoman". In Anatolia çorlu means "someone who is possessed and has mental disease" and the exorcist is called çoraman (Karakurt 2012, p. 251). The word çor itself disappeared from Tatar and Chuvash, leaving traces of its initial meaning, for example, the word çir which means "disease", so çirle means "someone who has a disease" generally. In the Tatar language a synonym for that word is cenle, which clearly refers to the belief that mental diseases or paralysis are due to a jinn's interference. Likewise, in the Turkish language cinli means "possessed, haunted, bewitched, demoniac, demonical". "If the forest people were angered, they could keep one in the forest, so that it became available to find one's way anywhere. Especially if, when wandering in the forest, one happened to hit on the Forest Spirit's track, one was sure to become lost. Those who had thus been bewildered by the Forest Spirit were called 'forest-bewitched" (Holmberg 1927, p. 186). This tale makes it clear why Şüräle is "forest-bewitched". Furthermore, the word Şor in Mongolian language means "swell" and associated with a horn (Karakurt 2012, p. 252) which, by the way, Arçura/Şüräle has and he is causing illness, e.g. "swell”. Çuralı/Şuralı had a paronym Çüräle/Şüräle.

No matter which theory proves to be correct, we can be sure that Arçura and Şüräle have the same origin, both are derived from the forms çor/çur/çura. In this paper the Volga-Ural Forest Spirit is referred to under the most common names used by the Tatar and Chuvash people: Arçura and Şüräle. The second one, Şüräle is also known and used by the Bashkir and Mari people.

\section{The Genesis of Forest Spirits}

There are many views concerning the origins of Arçura and other Forest Spirits in the Volga-Ural peoples' folklore. However, they share one common feature: all Forest Spirits are the souls of people. Targeldesh in Mari mythology is a one-eyed human soul who died with unnatural death (Enderov 1984, pp. 50,13, 14). Even a horse that dies in the forest is believed to move in the night and to attack wanderers. The Mari call it "horse-Targeldesh" (Holmberg 1927, p. 33). The same can be found in Udmurt mythology as Palesmurts (Vladykin 1994, p. 100). "According to Finno-Ugrics the souls of sacred bears, other animals, and those who die in the forest" (Jobes 1962, p. 594). As we can see from Benzing's article, the cause of death is sometimes said to 
be an accident in wood-cutting, cold weather etc., but for the most part it is due to murder: strangulation or exposure of illegitimate children, and removal of old and sick people who are incapable of working: "Formerly men knew no God and no justice. They were afraid of supporting the one-eyed, blind, lame and those old ones who were incapable of working, took them into the forest and killed them there. In the same manner as they had been crying when dying, their souls cry as they haunt the forest" (Benzing 1947, p. 82). Arçuras also arise from those who have committed suicide, into whose corpses the devil wraps himself so as to frighten people or the souls of those whom God does not take to himself, so that they wander lamenting (Benzing 1947, p. 82). According to the Mari people the anthropomorphic Forest Spirits were originally human beings. It is believed that those who died in the forest become Forest Spirits or their assistants. On the site of their death they frighten people and cause them to lose their way so that they too may die (Holmberg 1927, p. 186). These tales make clear why Arçura plainly has $a r$ in its etymology: because he is an "assistant". Buryat tales relate how a hunter was once lost in the forest, finally dying of hunger, and how this unfortunate man became the Forest Master (Holmberg 1927, p. 466). In Mongol mythology çötgörs are the souls of dead people who bring evil to the living (Heissig 1980, p. 14). So arçuras originate in people who died an unnatural death, or sometimes it is said that they had no extreme unction or no death-prayers were offered for them and their corpses were not covered with mould which is an indication that the Arçura arises from the shank bones (Benzing 1947, p. 82).

As can be seen there are numerous reports about Arçura's genesis, however, there is none about the genesis of Şüräle. This can be explained by the fact that Şüräle is not a "forest-witch" but "forest-bewitched" (Holmberg 1927, p. 186). Formerly, they were ordinary people as described in some Tatar folk narratives: "Yarımtıq lived in our village, he used to be a human. Someone bewitched him and could not come back to the village. After wandering and eating different plants, he became Yartmtiq. Hornless. Nude. Not shaggy" (Ğiyläcetdinov 2000, p. 283). However, apart from their origin, not much difference can be observed between these two mythological creatures.

\section{Where Do the Forest Spirits Live and Their Marriage}

The tales of the Volga-Ural peoples make clear why the Masters of forests and water seek the company of humans, and aspire to have marital and other ties with them. In some fairy-tales there are motifs in which a man married the daughter of Forest Demon or a Forest Demon married village girls. In a Mari fairy-tale Forest Demon's mother is shown as a Devil (Aktsorin 1984, p. 218). This motif is not peculiar to the Volga-Ural region as it can be met with also in Scandinavian folklore, where a human got married to Jätte (Kvideland-Sehmsdorf 1991, pp. 305-306) and female Forest Demon: "sometimes, she will even wish for sexual intercourse with a Lapp" (Holmberg 1927, p. 177). In Western Finland the Metsänneitsyt "Forest virgin" is in love with men, and entices them to cohabit with her (Holmberg 1927, p. 185). According to some legends, after someone's marriage with Şüräle, a tribe came into existence 
called ‘Şüräle generation' (Tatar Mifları 1996, pp. 148-152; Tatar Xalık İcatı 1987, pp. 269-276; Başqort Xalık Ícadı 1980, p. 112).

This type of motive can be seen also in Udmurt folklore where a man hunter called Imanai fell in love with the daughter of the Forest Demon and they got married. But when he brought her home and started living together with her he forgot the advice of the mother Forest Demon, i.e. representative of another world. As a result the daughter of Forest Demon cannot live among people and dies (Potanin 1884, pp. 240-241).

Some forest demons, for example Yarımtıq in Tatar folklore, Nyulesmurts and Ludmurts in Udmurt mythology can also come to human habitation (Vladykin 1994, p. 100). “... Forest Spirit also goes to the villages, where he sits down with the people and takes part in their feasts. He also arranges feasts and weddings in the forests, where he has a magnificent home and a large family, servants and cattle." (Holmberg 1927 , pp. 182-183). When in a good mood he will go to the huntsmen's log-fires to warm himself, but when angry he puts the fires out (p. 182). Mordva Vir-ava "Forest mother" visits the villages in the form of a dog, a cat or a wolf. The Forest Spirit comes to the log fires to warm her long hands (Holmberg 1927, p. 184). The forest demon lives in a forest, either alone or has a family and children. If Şüräle has any difficulty he asks his/her next-of-kin or father for help (Enderov 1984, p. 52; Ğyläcetdinov 2000, pp. 278-283). Sometimes they will fight for their territory, knocking down trees and scaring animals.

Naturally, the usual abode of a Forest Spirit is in the forest. However, there are some types of forest demons like Vir-ava in Mordva folklore who live in fields and mountains. In some narrations they live in log houses which are half or fully under the ground, or in tree caves. The usual abode of the Mari Forest Spirit Kojla-ia is the forest, but he often visits the fields and meadows (Holmberg 1927, p. 182). There is another Mari evil Forest Spirit called Ovda that in addition to living in the forest is also said to dwell in chasms in the rocks and in the ruins of old castles (Holmberg 1927, p. 183). The Arçura lives where he arose, i.e. in dense forests, sometimes in a ravine, too (Benzing 1947, p. 82). In some Bashkir folk stories the Şüräle lives in a lake among reeds: "Şüräle... shouting ran towards Lake Serbeyn and disappeared. They mostly live there. They have a house among reeds" (Başqort Xalık Ícadı 1997, p. 440). It has a home and property in the forest (Holmberg 1927, p. 183). According to folk beliefs Şüräle's places hide treasure inherited from their ancestors. In case they find themselves in hardship they use it, also they give money and gold from that treasure to people who won them (Ğ1yl'manov 1996, p. 69).

\section{How Do Forest Spirits Look Like and Dress}

Very often Volga-Ural folk narratives are giving new information, sometimes complementing each other, sometimes repeating each other in regard to the description of the appearance of this forest creature. Although, the folklorist F. Urmançe in one of his works writes "according to information (in folk narrations) his appearance resembles 
a man" (Urmançe 2010, p. 172), in Tatar and other Volga-Ural peoples' folklore, this character is often presented also as a female: "body is a female body, hairy, with its breasts on its shoulders (Ğ1yläcetdinov 2000, p. 277), "an old man saw that a daughter of Şüräle is sitting on a horse. Her hair is bristling, has a horn on its forehead, very ugly, large breasted" etc. (Tatar Xalık Ícatı 1987, p. 172). The Mari Forest Spirit Ovda is naked, with long hair and large breasts which is sometimes thrown over its shoulders, and it is also covered with a hair. Sometimes it appears as a man, sometimes as a woman (Holmberg 1927, p. 183). Mari Şüräle is also anthropomorphic, but naked and hairy. It has only three long fingers on its hand (Holmberg 1927, p. 181).

The forest demon can talk like a human being. This causes the main trouble to people since the forest demon makes a sound asking for help and leads astray those responding to the sound and takes them to the darkest places of the forest. Holmberg writes about the Mari Forest Spirit Kojla-ia: "He can speak human languages and call the traveller by his name, and by pretending to be his friend, entice him into his power. People believe him and follow him until they can no longer find their way again. Thus the Forest Spirit causes people to become lost" (Holmberg 1927, pp. 182-183). "A long, dark, human-like being is also the Forest Master of the Buryats, who halloes and weeps in the forest, leads wanderers astray, but gives also game to the hunter" (Holmberg 1927, p. 466).

Alid in Udmurt and Leshii in Russian mythology "were believed to be able to accommodate their stature according to their environment. When they were wandering in the forest they were as tall as the trees, but when they appeared on the plains walking among grass, they become equal to it, and then they did not exceed the blades of grass in height" (Porteous 1928, p. 105). In this regard, Arçura also usually appears as a man, but he is able to change his size from a blade of grass to a very tall tree. The Mari Kojla-ia is also an anthropomorphic Forest Spirit who can change his height so that he can be as tall as a pine; sometimes he is called Targeldesh (Holmberg 1927, p. 182).

On some occasions we are assured that Alid has only one leg, also his/her leg is backwards, one big eye and a huge teat with which he/she squeezed peoples mouth and suffocates them (Bulychev 1995, p. 140). Similarly, the Mari Ovda wanders in the forest in the shape of a human being, but its feet are turned backwards (Holmberg 1927, p. 183). Palesmurts, Nyulesmurts and Ludmurts in Udmurt mythology also have a huge height (or they have an ability to change their height). "Şüräle has also pure mythological characteristics, with his/her height being greater than a human being; body covered with hair; with his/her thin and long fingers that like to tickle people" (Urmançe 2010, p. 172).

Arçura/Şüräle's walk like humans. Their arms are long. When they walk their hands come to their knees and sometimes their sharp nails touch the ground. They do not have any hair on their fingers; they are covered with lots of wrinkles. Arçura/Şüräle's body is shaggy or hairless, eyes are big, sometimes ears are very long, and breasts are hanging down. Skinny, in height they are almost the same as trees in a forest. However, "he/she still looks like a human, but different from a human being: fingers are long, nails are very hard and very long... breasts are like sacks. They sling 
their large breasts over their shoulders" (Tatar Xalık Ícatı 1987, p. 269). The Arçura appears in various human images (usual person, white-bearded old man, giant) or animal. He is often described as an ape (upäte) or as a tall hairy man (Benzing 1947, p. 82). The names of Forest Demon in Mordva, Udmurt and Bashkir folklore are $\mathrm{Pa}$ lesmurt, Alid and Yarımtıq, basically they mean "half man", "semi-" or "in-between". The Udmurt researcher V. Vladykin is of the opinion that "half-man" means the border position of the character between living and dead worlds, being and not being, "being with one foot in grave". It presents a divided human lengthwise: half head, half body, with one arm and one leg, the inside is visible (according to another narrative their other half exists, but "shows through") (Vladykin 1994, p. 100). In Tatar folk narratives there is another folk demon called Yarımtıq. As it is understood from this Forest Demon's name (yarım means "half"), the Yarımtıq is a half-bodied person, a single-eyed, single-handed, limping creature (Tatar Miflar1 1996, p. 168). Being one-eyed he resembles the Cyclops in ancient Greek mythology or Odin, the major god in Norse mythology, who sacrificed his eye in order to gain the Wisdom of Ages. We can see analogies in Scandinavian mythology. Hel, a Scandinavian underworld goddess is also described as half blue and half flesh-coloured and further as having a gloomy, downcast appearance.

It is known that semi-human: half-body, single hand, and single foot is not an unusual thing for mythology of many nations. As for Arçura/Şüräle, they are not "half" as they are not ancient gods who became transformed from first type into the second type, i.e. the ancient Finnic gods became transformed into demons after accepting Christianity. They were souls of ordinary people and for that reason they were seldom worshipped. They are invisible Nature spirits. "Master", "Lord", or "Ruler" is expressed in Tatar and Chuvash languages by the words Hoca, iyä, in Yakut itşi and Buryat Edji. "An invisible Ruler of this description is to be found in the sky and its phenomena, the stars, fire, land and forest, trees and grass, rivers and lakes, mountains and rocks, the different animals, and even in objects made by man, buildings, weapons, tools, vessels, etc." (Holmberg 1927, p. 464).

Although, Arçura/Şüräle is often described as a human who walks on two feet, speaks, can make jokes, etc., this Forest Demon has also animal characteristics: Arçu$\mathrm{ra} /$ Şüräle has a woolly body, very often has a horn on its forehead, lives in forest etc. Most Tatar people are acquainted with Şüräle from the poem of the famous poet Tatar Gabdulla Tuqay, who adopted the pseudonym Şüräle:

"What is this? Is it a lunatic, is it a ghost? Or something else? What is this?

This is a dreadful, a very unpleasant thing.

Its nose is bowed and crooked entirely like a fishing-hook,

The arms are not equal; the feet are like branches and boughs.

Its sunken eyes sparkle and glare.

It is dreadful if you see it, not only at night but even in broad day.

It is all nude, quite delicate; but it has the shape of man,

On its forehead it has a horn of the length of a middle finger."

(Benzing 1947, p. 77) 
The Mari Forest Spirit Kojla-ia (or Targeldesh as he is called in some districts) is said to have only one eye in the centre of his forehead (Holmberg 1927, p. 182). A Russian Leshii has a human body, from top to half of its body, with goat horns, ears and beard on its head, beyond the waist it has goat legs. According to this description they are very similar to Ancient Greek Satyrs (Ivanova-Kazas 2004, p. 121).

Arçura/Upäte can be male or female, they have the form of an ape, they are shaggy and have a big head, long hair and a black face; four eyes, two of them in front and two behind, and moreover three hands and feet (Benzing 1947, p. 82).

In Tatar mythological fairy tales it is often mentioned that an Arçura/Şüräle has big teats. This also took the attention of Kayum Nasiyri (1825-1902), eminent figure of 19th-century Tatar scholarship. In his work called "Beliefs and customs of Kazan Tatars which Appeared Without Islamic Influence" he writes as follows: "Şüräle. Something like Leshii among Russians ... Şüräle's teats are big, one of them will be put on the right, the other one will be put on across the left shoulder" (Nasiyri 1975, p. 58). This is also the same in Mordva folk narrations: "He/she (Vir-ava) puts his/her teats under his/her head when sleeps". Because his/her teats are big, their underneath is always flesh. They say, if you touch salt on it, he/she will die. For that reason, people when they are in the forest say to each other "Bring your bitter" to scare him/her (Ğlyläcetdinov 2000, p. 282). A human being can overpower the Forest Spirit if he knows how to touch it on the left armpit, where there is a hole, the Forest spirit becomes powerless immediately when touched there (Holmberg 1927, p. 183). For that reason, the Şüräle never raises his/her arm, because a branch may come into that hole. Furthermore, this Forest Demon always wraps up himself with bad pieces of materials and is trying to wear an old fur hat. The reason is clear: Arçura/Şüräle has a horn on his/her forehead. This Forest Demon is trying to hide that horn with a fur hat. In the Folk-poetry of the Finns, "the King of Lord or Mistress of the forest" has "a hat of pine-needles", a "blue mantle", and a "beard of leaves" (Holmberg 1927, p. 189).

As for Finno-Ugrian Forest Demons, "their hats are made of pine needles, their mantles are blue, and their beards are leaves, thus they are nature spirits, personifications of light (or darkness), cold, wind etc." (Jobes 1962, p. 594). As in Chuvash mythology the Arçura, has a garment; when any man finds this garment and puts it on, nobody is able to see him. So, using it one may become very rich. "But one must not doff the garment. Once when the man was returning from the town it was very hot, and he put the garment in his carriage; then a wind came and carried it away. The Arçura had caused the wind to carry away the garment. Since that time nobody is able to find this garment" (Benzing 1947, p. 83). The Russian Leshii has an ability of appearing as a human being but without a shadow. However, the Forest Demon can be identified by its big, green beard which gives it away (Ivanova-Kazas 2004, p. 121). Like Leshii Arçura also has no shadow.

Like the animal spirits dwelling in the forests, the animated forest itself aspires to have anthropomorphic features. In attempting to simulate a human being, however, it cannot hide its original self. Standing among tall pines, the Forest Spirit is of the same height as these and moving in the underbrush it again shrinks to the height of that particular thing, i.e. the underbrush. The Mordva Forest mother, when in the shape 
of a human being, has still feet as clumsy and thick as logs, and the Forest virgin of the Finns, beautiful from a front view, appears from behind as a rotten stump or a bushy tree (Holmberg 1927, pp. 188-189). Also, the Scandinavian Wood-Wife known also as Huldra, "sometimes appeared as young and beautiful but at other times she was old and ugly; and some accounts of her say that she was lovely in front, while behind she was hideous and hollow" (Porteous 1928, pp. 100-101). Sometimes he appears as a forest-animal, a dog, an owl, or also a hay-stack, a stump etc. He moves from one place to another as a whirlwind (Holmberg 1927, p. 182). The Mari forest demon Ovda also moves as a whirlwind, so the trees bend to the ground (Holmberg 1927, p. 182).

Chuvash Obyda, which wanders in the forest as a human being, is naked, longhaired, with large nipples, and with feet turned in the wrong direction. Having caused a man to lose his way, it tickles or dances its victim to death. The poor animal on whose back Obyda seats himself begins to run backward. According to folk-tales this spirit itself wanders backwards (Holmberg (1927, p. 468). Similarly Mari Şüräle who has descended from the Chuvash (Holmberg 1927, p. 183) "calls all night in the forest, causes people to lose their way, and entices them to itself. At times it rushes suddenly upon people, tickles them or dances with them until they are completely exhausted. Often it will mount a horse in the meadows and ride it madly round the fields until the horse nearly falls" (Holmberg 1927, p. 181). However, this motif is from a narration about another Çor: "The Red Mother" which is merged with the belief about the Şüräle: "she travelled by night on stolen horses, galloping them until they were exhausted, then abandoning them" (Kerrigan 1998, p. 123). In the worldview of shamanism spirits have different properties from beings with physical bodies, they can fly and travel anywhere with tremendous speed.

So, Arçura/Ş̈̈räle assume different shapes so that they may be seen in different forms, except in the motif of the wedge in the fissure that is employed for warning Arçura/Şüräle which has been made known to the Tatars primarily thanks to the literary work of Ğabdulla Tuqai.

\section{Pleasing the Forest Spirits}

Arçura/Şüräle's role is contradictory. It could bring luck, but also troubles, leading humans to wilderness. Cutting a tree was not that easy. People who were living and interconnecting with nature, had no right to pollute and destroy any kind of life in it. Therefore, people were very careful not to offend the Forest Spirit, and when a tree had to to be cut out, sacrifices were given to please the tree/Forest Spirits. Their power was of a nature to be dreaded, and mysterious illnesses affected those to whom they took an ill will, while in many cases death followed an offence against them. Spiritually powerful places in nature require respect of the spirits that dwell there. Insults to the spirits can result in their attack on the offending person or his community. On the other hand, honouring the spirits of these places brings good luck and prosperity (Sarangerel 2000, Chapter 3). Forest Demon gives "rain and sunlight", "improves crop", 
"provides increase in the number of cattle and grants children" (Frazer-Doğan 1991, pp. 68, 71, 73). This offering is inseparable part of shamanist practices. Nonetheless, not always the offerings will help as the Forest Demon is usually a mythical being of a malevolent type. But the Forest demon in Finno-Ugrian folklore in some instances may have a beneficent character. Eastern Lapps' Miehts-hozjin "The Master of the Forest" or Vare-jelle "Forest-dweller" "does not do any harm to human beings unless provoked. When anyone shouts, sings or makes a noise in the forest, he becomes offended, and bewilders the culprit so that he cannot find his way out of the forest. The Master of the forest loves silence above all" (Holmberg 1927, p. 177). Similarly, Arçura's are not evil: although they enjoy misguiding humans and kidnapping young women, they are also known to keep grazing cattle from wandering too far into the forests and getting lost.

To fall into the power of the Forest Spirit is dangerous, as he tickles people to death: the Mari Targeldesh "frightens people and causes them to lose their way so that they too may die." (Holmberg 1927, p. 33). Another Mari forest demon Ovda is feared because it approaches people, enticing them to dance or wrestle with it, when it tickles or dances them to death (Holmberg 1927, p. 183). The Russian Forest Demon goes around the people walking in forest, then by mixing up memories make them lose their way and after that takes them to their homes (Ivanova-Kazas 2004, p. 121).

We can see that "harmless" qualities also in Volga Finns: "Vir-ava (Viryava) could rescue a person who got lost in the forest, but could also kill by tickling to death" (Jobes 1962, p. 594). Vir-ana, in Mordva mythology, likes listening to fairy tales and there is a solution to avoid the demon: people who come to the forest can start to work (collect strawberries, cut wood) only if they find Vir-ana asleep. Nyulesmurts and Ludmurts in Udmurt mythology say that the Forest Spirit is stupid, and likes to amuse people (Vladykin 1994, p. 100).

Among the Baltic Finns the Forest Spirit is called Metsänhaltia "Forest ruler", every forest possessing one of these beings (Holmberg 1927, p. 184). The Mets-haldijas "Forest ruler" is known also among the North Estonians, his cry in the forest means that something special is about to happen, e.g. a death (Holmberg 1927, p. 185). As can be seen, he is a "ruler"-deity who is aware of humans and asks for offering and sacrifices, especially from hunters: "Among the numerous Gods who presided over the destinies of Finland was a special God of the forest named Tapio, to whom all the wild beasts of the forest belonged, and over which his beautiful goddess reigned. To these sylvan deities the hunter had to appeal for permission ere he ventured to hunt or slay any of the forest animals, and oblations were offered to them to induce them to drive the game across the hunter's path" (Porteous 1928, p. 108). When a Mari makes offerings to the Forest Spirits he addresses them mostly by their names Košla-Kuguza "Old man" and Košla-Kuva "Old woman of the forest". He asks them for protection in the spring when he sends his cattle out into the forest. When a hunter goes out hunting he cuts a little opening in a tree and puts in a piece of bread for the Forest man, in the hope that the latter will help him by driving game into his path. The "Old man" and "Old woman of the forest" are further appealed to when a 
person is lost in the forest or wishes to spend the night there, and in the sacred groves, the people never omit to pour a drink-offering on the ground for the "Forest man and Forest woman". (Holmberg 1927, p. 184). Sometimes hunters make an offering to the Leshii, i.e. they put a salted hunk of bread and tobacco on a stump (Ivanova-Kazas 2004, p. 121). Many North Siberian tribes, for whom hunting is an important means of subsistence, have a habit, at the beginning of the autumn hunting season, of sacrificing a part of the first "bag" to the Forest Monster (Holmberg 1927, p. 467).

Although, the divine religions had influence on the old Gods, they left the mythological creatures whilst a few new types of Forest monsters were added to the existing ones. The reason for the birth of these new characters was that people perceived their environment as alive and changing. However, Arçura/Şüräle is different from Forest monsters that were transformed from gods. As Holmberg wrote about the Arçura/Şüräle: "Here the Forest Monster, corresponding to Russian spirits, chiefly an evil being, which is seldom worshipped. In this respect is different from the Forest Spirits of the most northern primeval forests of Siberia" (Holmberg 1927, p. 467). In one report Christian Tatars are said to have sacrificed a "white cock" for Şüräle when they come to forest, but I doubt whether this singly recorded belief has an original relation to Arçura/Şüräle. However, it is most likely pleasing to Forest Spirits (Şämsi 1984, p. 147). The ancient Mongols believed in a supreme god of eternal Heaven, Möngke Tengri. Beneath this all-powerful divinity, there were many lesser deities, each with an allotted place on the branches of a huge cosmic tree (Kerrigan 1998, p. 113). "The lowest level in the Mongol cosmic hierarchy was occupied by innumerable demons with grotesque human bodies, horns, tails and hideous masklike faces. They haunted the steppes, playing pranks on travellers" (Kerrigan 1998, p. 123) which is exactly what Arçura/Şüräle is and therefore he is not worshipped. In this respect Şüräle differs from the Forest demons of Northern Europe.

\section{Do's and Do not's concerning Arçura/Şüräle}

In Tatar folklore Arçura/Şüräle, similarly to Yarımtıq at the Bashkirs, and other forest demons are known as stupid and gullible. We can find parallels from North European mythology (see Brasey 2003, p. 172). To escape the evil will of Arçura/Şüräle one must tell a lie and mislead it. People learnt the ways of getting rid of them. Some examples are as follows:

- When you hear the Arçura/Şüräle crying in the forest, you must answer, he comes and eats you. When you call, however, you must call 4-5 times, then the Arçura/Şüräle says: "People are aping me", and does not approach you (Benzing 1947, p. 84).

- Never help them when they ask for help. If they invite you to play tickling, never accept that offer. When you meet Arçura/Şüräle, do not show your teeth. Otherwise, Arçura/Şüräle will think that you are laughing and start tickling you. This will mean your end. Never laugh. Otherwise, Arçura/Şüräle will get excited. 
- Arçura/Şüräle asks a lot of questions. The only way to escape this is to ask Arçura/Şüräle questions as he/she does not like being asked questions.

- Do not go to forest alone as Arçura/Şüräle attacks only lone people.

- When Arçura/Şüräle meets a person, ask "Is there a dog? Is there a whip?" since Arçura/Şüräle is scared of dogs. When they hear dogs' barking, they immediately run away. If you do not have a dog with you, it would be enough to call any dog's name. A dog in mythology "symbolises dawn (the hound of heaven); is an aid, through scratching, to rebirth, a destroyer of evil, guard of the underworld" (Jobes 1962, p. 456).

- Arçura/Şüräle does not like whips. So, make a sound of a whip. The fact $A r$ çura/Şüräle does not like whips, must be a leftover from the shaman's magic whip, known as taşur or minaa, often made from a horsetail with a handle fashioned of willow or tamarisk wood (Sarangerel 2001, p. 255).

- Arçura/Şüräle does not like the word "bitter" and is scared of salt. Apart from that, is also scared of fire, as well as axes and other sharp tools, if a man keeps them in his hands (Benzing 1947, p. 84). According to shamanic belief, there is an invisible Ruler of everything, even in objects made by man, buildings, weapons, tools, vessels etc. "Especially, in sharp or 'living' weapons, with which it is easy to harm oneself, such as knives or axes" (Holmberg 1927, p. 464).

- Arçura is afraid of a cross made of ash tree, nor does he approach an ashwood fire to warm himself (Benzing 1947, p. 84). We see here the motif of ash tree, which is sacred and a close remedy at hand, combined with Christianity as "The Rev. M. D. Conway says that when Christianity was introduced into Northern Europe the ancient Scandinavian gods became transformed into witches, and that the Ash was their favourite tree" (Porteous 1928, p. 85). Also, the Arçura is afraid of the mountain-ash; therefore many Chuvash carry small crosses or crucifixes of mountain-ash wood with them (Benzing 1947, p. 84). As for Palesmurts, Nyulesmurts and Ludmurts in Udmurt mythology, you need to mention the name of sky god Inmar and hide yourself behind a rowan tree (Vladykin 1994, p. 100). Both the Baltic and the Volga Finns believed in its protective powers, though offerings were not made to this tree (Holmberg 1927, pp. 187-188). This is because "the Rowan tree was held in the utmost dread by witches on account of the mystic properties which were believed to encompass it" (Porteous 1928, p. 86). Juniper is used by shamans for rituals to cure the partial paralyses of a person's face, but can be applied to any kind of illness caused by çötgör intrusions (Sarangerel 2000, Chapter 5). Also, it is essential to obtain a metal or nephrite mirror.

- It is almost impossible to escape from the Arçura/Şüräle running after you as the Forest Spirit runs so fast and as his/her body looks like a tree, it is not noticeable. When lost in this way in the forest, one must change the right boot on to the left boot, and vice versa, to find one's way home as the Forest Spirit will be going to the wrong side by following your footsteps. Also to hide your way you need to walk in reverse. If you do that, the Arçura/Şüräle will be running to the wrong side. 
- The Arçura/Şüräle is very afraid of springs, brooks, and water in general. When he approaches a man, he often asks: "Are you going towards the source or towards the mouth?" About the answer there is no unanimity; one report reads: "When the Arçura/Şüräle is told 'towards the mouth', he comes; when we answer 'towards the source', he runs away" (Benzing 1947, pp. 83-84).

- The person who the Arçura/Şüräle is chasing after should run towards running water. If you can get onto the other side by jumping or swimming, the Arçura/Şüräle will not be able to do anything to you as it is scared of water. But if the Arçura/Şüräle learns the source of the water, the Forest Demon will come to the other side by running there very fast and catching you anyway. That is why if the Forest Demon asks "Where is the beginning of the water?" you should point out the side where the water flows to. So this way, the Arçura/Şüräle will be going there and reach the sea. Thus the Arçura/Şüräle will get lost and you will get rid of the Forest Demon. (There is a saying among Tatars: "To show Şüräle the beginning of the water" which relates to this story.)

- When the Arçura/Şüräle comes to you, pour drinking water all over your body and make yourself thoroughly wet. You will escape the Arçura/Şüräle as the Forest demon does not tickle wet people.

- Tricking him to squeeze his fingers. This game was invented by a young man called Bıltır. When a Şüräle came to him to engage tickling, he cut an oak cudgel, split it, and pushed a wedge into the fissure. Blltır asked the Şüräle for a favour: to keep a gap on a log open. Then when Blltır struck it with an axe, the wedge became loose, and the Forest Demon's fingers remained squeezed in. Bıltır left Şüräle in that position and saved his life from being killed by tickling.

- To spread tar on a horse's back. One of the weaknesses of the Arçura/Şüräle is that this forest Demon loves riding a horse. The Forest Demon would choose the best horse from the horde and enjoy riding on it all night. When Tatars see a horse, any horse from a horde that comes back in a sweat, they believe that it was ridden by Arçura/Şüräle. Sometimes people sent the best horse with tar spread on its back. The Arçura/Şüräle would get stuck on it and could not come down. As a result, the Arçura/Şüräle had to come to village on a horse. Mostly when a Arçura/Şüräle was caught on a horse, people would kill it by torturing, stoning and beating it with cudgels. Sometimes people would lock the Arçura/Şüräle in a bath and kill him in smoke or burn him alive.

\section{Arçura/Şüräle as a Victim, Curser and Avenger}

Generally, all discarnate souls are capable of causing illness and stealing souls, even without such intent. So, meeting with an Arçura/Şüräle does not bring a human being any good luck. According to Mordva belief, the person who even just saw Vir-ava will get sick and die. The Arçura/Şüräle jostles people and makes them sick (Benzing 
1947, p. 83). To see the Forest-people is not a good sign, as very often some accident, sickness, or death follows (Holmberg 1927, p. 183).

"One day a shepherd while he was herding horses, got scared of a bear and went up to a tree where he started to play qubiz. A Şüräle came in the forest to the sound of qublz and started dancing under the tree. When he finished dancing, he asked 'Hey, man, I am also coming up to the tree to you, ok?' The man said: 'Come.' The Şüräle climbed on tree and held tree branches with hands. The man made the Şüräle fall down by hitting the Spirit's hands with an axe handle" (Ğyyl'manov 1999, p. 71). It seems that the divine religions replaced the shaman with a shepherd who is sitting on the tree and playing on a shamanic lute-like instrument qubiz: "a way of travel to the upper world for a shaman to climb the turge, the world Tree" (Sarangerel 2000, Chapter 1).

The most common and climactic point of narratives of the Arçura/Şüräle is the tale about squeezing his fingers: a young man called Brlttr cut an oak cudgel, split it, and pushed a wedge into the fissure. The man knocks several times, the wedge becomes loose, and the Forest Spirit's fingers remain squeezed in. So, to avoid the Forest Spirit by using a trick, when asked his name by the Forest Spirit, he introduced himself as Brltur which literally means "last year". In the morning when he was shouting for help to other forest-demons, the relatives and friends came and told him: "O fool! When Last-year squeezed, do they cry then this year!" (Ğaynanova 1964, p. 240). Actually, the name Bilttr recalls the name of Baldr (also Balder, Baldur) a god of light, spring and purity in Scandinavian Mythology (O'Donoghue 2007, pp. 74-77), who died but one day will emerge. It is possible that this god remained but in the form of a human saviour in the Volga-Ural region as the Forest Demon is much afraid of spring (Benzing 1947, p. 83). Sometimes, no more than a name remains in the literary record or the slightest hint of a shadowy role or function in the great scheme of things. But the humanity of the gods extends beyond physical form. It might be a combination of ancient Finno-Ugric beliefs with Shamanic traditions for example the Çötgör is also afraid of light, yells, and violent movement which are used in shamanic techniques (Sarangerel 2000, Chapter 3). Also, in one report it is said of the Arçura/Şüräle "God killed them by means of lightning in order that they should no more frighten anybody" (Benzing 1947, p. 84). These motifs are not seen in other Turkic and Altaic narrations.

However, even after having escaped Arçura/Şüräle by a trick, a man later on would always have big problems, disease even death. In Mari folklore there is a fairy tale about a forest demon: a man goes to the forest for hunting and comes across the forest demon. The man shoots the demon and wounds him. In the morning the man finds out that the skin of the demon is magic: whoever and whatever touches it becomes invisible. The man started using the skin and becomes rich. However, this does not last long as Forest demon's friends take revenge for him and burn out his wealth (Aktsorin 1995, pp. 52-54).

In one of the stories it says that people gathered and started to beat Arçura/Şüräle with axe handles as if they kill a Forest Demon by shooting. Just one drop of 
blood on the ground makes thousands of Arçura/Şüräles to come into existence (Benzing 1947, p. 82).

People who behaved cruelly towards Arçura/Şüräle, will never live in peace. Here we see the motif of the curse as in numerous Tatar fairy tales. Şüräle's curse came true. "When Şüräle died, he cursed: 'May your village not have an increase of six houses, not reach seven houses.' After that only six houses among all sixty houses survived, the rest burned down in a fire. Their village is still not increasing six houses" (Ğıläcetdinov 2000, p. 280). Another story states "Şüräle ranted and raved, finally crying a curse: 'May your village not increase six houses' and headed towards Qibla Mountain. The village since then did not increase six-seven houses" (Cen-Pärilär Bar Dilär 1992, pp. 53-57). In some narrations it sounds like a prediction: in order to escape from punishment, Şüräle predicts the future of the village: “... right now you have two houses in your village, it is possible to increase two to four. But if you want you have six houses, do not even start making its log home. No luck" (Başqort Xallk Ícadl 1997, p. 52). As mentioned above, to see the Forest-people is not a good sign, however among Tatars there is a belief that a Şüräle during his life changes his fingers a few times and one who finds them while going through the forest is considered as a lucky person. These stone "fingers" are called Belemint in scientific language and it is believed that if they are crumbled and sprinkled on a wound, it will recover quickly (Ğiyl'manov 1999, p. 69).

Furthermore, it seems that, folk even sympathise with him and regard sending him to "Qibla" Mountain as a kind of "holiness" (Qibla means direction of Mecca). There was a cult of high places among Altaic peoples (Heissig 1980, pp. 101-110) and it was believed that "Perhaps, this is the mountain which was "in the centre of the earth there is an iron mountain and on this iron mountain a white, seven brunched birch" (Holmberg 1927, p. 349), later on replaced with Holy Mountain of Hira near Mecca. However, Forest Spirits are mainly described in a negative way.

\section{Summary}

Actually, the notion of Arçura/Şüräle is present not only in Chuvash and Tatar mythology, but belongs to the shamanic Çor/Çura family, similarly to other mythological creatures such as the Abaasl/Albastl. It preserved the common Altaic shamanic tradition, even though with some variations. These variations, which were formed gradually as a result of the socio-cultural life of the Volga-Ural peoples, reflect local characteristics. The relatively early transition of the Volga Bulgars to settled life, the formation of urban culture and the embracement of divine world religions, induced the weakening of the shamanic mythical tradition. Some mythical characters were preserved while some others faded away, so the disappearance of Arçura from Tatar and Biçura from Chuvash mythologies does not mean that they belong solely to this or that particular ethnic group. It seems that Arçura/Şüräle is a product of "myth demolishing" (Eliade-Rifat 2001, p. 143) period. 
Furthermore, there are numerous pure shamanistic attributes preserved. Arçu$\mathrm{ra} /$ Şüräles are human souls who died with unnatural death, and they like stealing and riding a horse. The Arçura/Şüräle is much afraid of dogs and bone-gnawing animals in general, and a dog is used to frighten the Arçura/Şüräle. Moreover, the Arçura/Şüräle avoids axes and other sharp tools, if a man keeps them in his hands (Benzing 1947, p. 84). According to shamanic belief, there is an invisible Ruler of everything, even in objects made by man, buildings, weapons, tools, vessels etc. "Especially, in sharp or "living" weapons, with which it is easy to harm oneself, such as knives or axes" (Holmberg 1927, p. 464). The fact that the Arçura/Şüräle does not like whips, must be a remnant from the shaman's magic whip, known as taşur or mina.

Consequently, the Arçura/Şüräle in Volga-Ural folklore is presented in two ways. The Forest Spirit is dangerous and powerful on the one hand, he is narrowminded and stupid, who can be conned easily, on the other. Because of his/her stupidity the Forest Spirit has a nickname 'forest sheep'. "When Christianity was introduced into Northern Europe the ancient Scandinavian gods became transformed into witches" (Porteous 1928, p. 85). In this respect the Şüräle differs from the Forest demons of Northern Europe as we have seen from the etymology it is not a "forest-witch" but "forest-bewitched" although even Arçura was seldom worshipped. The difference between Arçura and Şüräle is that the Arçura is a "forest-witch" (Çura) and Şüräle is "forest-bewitched" (Çuralı and/or Çura ulı) (Holmberg 1927, p. 186).

The belief relating to the prohibition of shedding blood of Arçura/Şüräle is connected with "a belief that the soul is in blood" (Frazer-Doğan 1911, p. 240) which prevents the bloodshed of human being as it creates Arçura/Şüräle. When Arçura is killed or wounded, every drop of blood becomes a new Arçura (Benzing 1947, p. 82). When a Şüräle was killed by certain villagers it cursed that place and the bounty was removed from there.

As these spirits are found throughout nature, it is considered taboo to offend them by needlessly damaging natural features or mutilating trees. An angry nature spirit Arçura/Şüräle is very powerful and can create many problems for a person or community until a shaman can placate or control it.

Thus, the mythology teaches people not to murder, not to commit suicide, to look after each other, especially elderly people, not to have illegitimate children, not to commit adultery and in case of death to offer funeral-prayers. The belief in mythological creatures inspired and stimulated people to look at their natural environment with respect. Also, it taught people to be clean and careful, to do and finish things on time. So, belief in and respect for the spirits of nature contributed to the formation of an ethic that minimises negative impact on the earth. Accordingly, the goal of life was to live in balance and harmony with the natural world.

Arçura/Şüräle, as a Forest Spirit, left an important imprint on the Volga-Ural peoples' folklore and the belief in it could not be completely wiped out from the memory of the people even in the Soviet period when mythological creatures were looked at as expression of superstition and backwardness. The Tatars who started coming back to their own cultural roots and heritage in the 1990s, called the park in 
the centre of Kazan, capital of Tatarstan, Şüräle. Apparently, Şüräle became one of the key symbols of Tatar culture.

There were lots of poems, stories, dramas and a ballet (Ballet Şüräle of Farit Yarullin) written and statues erected (for example, Baki Urmanche's Şüräle Statue), and pictures drawn. Also the Chuvash poet Mikhail Fedorov wrote a poem about Arçura called "Arzyuri".

It appears that even today a spiritual interconnectedness exists among the Volga-Ural peoples. Their common belief in a Forest Spirit, similarly to other mythological beliefs, help them perceive themselves as part of the universe.

\section{References}

Aktsorin, V. (1984): Mariiskie narodnye skazki. Yoshkar-Ola, Mariiskoe Knizhnoe Izdatel'stvo. Aktsorin, V. (1995): Mariiskii fol'klor. Skazki gornykh mari. Yoshkar-Ola, Mary Kniga.

Başgöz, İlhan (1972): Folklore Studies and Nationalism in Turkey. Journal of the Folklore Institute No. 9 (2/3), pp. $162-176$.

Başqort Xalık İcadl. Rivayättär häm legendalar (1980). Ufa, Başqortostan Kitap Näşriyatı. Başqort Xalık İcadl. Rivayättär häm legendalar (1997). Ufa, Başqortostan Kitap Näşriyatı.

Benzing, J. (1947): 'The Forest-Demon'. A Tatar Poem of Gabdulla Tuqay. BSOAS Vol. 12, pp. $73-85$.

Brasey, E. (2003): Dragons, Little People, Fairies, Trolls and Elves. London, Hachette Illustrated UK.

Bulychev, K. (1995): Fantasticheskii Bestiarii. Saint Petersburg, Izdatel'stvo KN.

Cen-Pärilär Bar Dilär... . Tatar Xalık Legendaları Häm Mifları (1992). Kazan, Journal Kazan.

Eliade, M. - Rifat, S. (2001): Mitlerin Özellikleri. İstanbul, Om Yayınları.

Enderov, V. (1984): Obraz Leshego v chuvashskom fol'klore. Issledovaniia po chuvashskomu fol'kloru Nauchno-Issledovatel'skii IYLI I Ėkonomiki Pri Ministrov ChASSR. Cheboksary.

Frazer, J.-Doğan, M. (1991): Altın Dal: Dinin ve Folklorun Kökleri [= The Golden Bough: The Roots of Religion and Folklore]. İstanbul, Payel.

Ğaynanova, F. (1964): Tatar Xalık Äkiyätläre. Kazan, Tatarstan Kitap Näşriyatı.

Ğıyläcetdinov, S. (2000): Tatar Xalık Rivayätläre Häm Legendalarl. Kazan, Rannur.

Ğıyl'manov, G. (1996/1999): Tatar Mifları. Kazan, Tatarstan Kitap Näşriyatı.

Heissig, W. (1980): The Religions of Mongolia. London-Henley, Routledge \& Kegan Paul.

Holmberg, U. (1927): The Mythology of All Races, Vol. IV, Finno-Ugric Siberian. Boston, Marshall Jones.

Ivanova-Kazas, O. (2004): Mifologicheskaia Zoologiia. Saint Petersburg, Filologicheskii Fakul'tet Sankpeterburgskogo Gosudarstvennogo Universiteta.

Jobes, G. (1962): Dictionary of Mythology, Folklore and Symbols, Part 1. New York, The Scarecrow Press, Inc.

Karakurt, D. (2012): Türk Mitoloji Ansiklopedisi: Türk Söylence Sözlüğ̈̈: https://turandursunkutup hanesi.files.wordpress.com/2013/04/turk-mitoloji-ansiklopedisi-deniz-karakurt.pdf

Kelényi, B. (2003): Demons and Protectors. Folk Religion in Tibetan and Mongolian Buddhism. Budapest, Ferenc Hopp Museum of Eastern Asiatic Art.

Kerrigan, M. (1998): The Diamond Path: Tibetan and Mongolian Myth. Amsterdam, Time-Life Books. 
Kvideland, R.-Sehmsdorf, H. (1991): Scandinavian Folk Belief and Legend. Oslo-London, Norwegian University Press.

Nasıyri, Q. (1975): Saylanma Äsärlär, Vol. 2. Kazan, Tatarstan Kitap Näşriyatı.

O’Donoghue, H. (2007): From Asgard to Valhalla. London-New York, L. B. Tauris.

Porteous, A. (1928): Forest Folklore, Mythology, and Romance. London, George Allen \& Unwin Ltd.

Potanin G. (1884): U votiakov Elabuzhskogo Uezda. Izvestiia Obshchestva arkheologii, istorii $i$ etnografii pri Imperatorskom Kazanskom universitete, Vol 3. Kazan.

Purev, O. - Gurbadaryn, P. (2007): Mongolian Shamanism. Ulanbaatar, Admon.

Radloff, W. (1960): Versuch eines Wörterbuches der Türk-Dialecte. s'Gravenhage, Mouton \& Co.

Rudenko, S. - Kurban, R. (2001): Başkurtlar. Konya, Komen Yayınları.

Sarangerel (2000): Riding Windhorses: A Journey into the Heart of Mongolian Shamanism. Rochester, Vermont, Destiny Books.

Sarangerel (2001): Chosen by the Spirits. Following Your Shamanic Calling. Rochester, Vermont, Destiny Books.

Şämsi, S. (1984): Tatar Mifologiyäseney populyar obrazı. Borınğl Tatar fol'klorı mäs'äläläre. Kazan, Tatarstan Kitap Näşriyatı.

Tatar Miflarl (1996). Kazan, Tatarstan Kitap Näşriyatı.

Tatar Xalık İcatı. Rivayätlär häm legendalar (1987). Kazan, Tatarstan Kitap Näşriyatı.

Urmançe, F. (2010): Tatar Mifologiyäse: Ėntsiklopedik Süzlek. Kazan, Mäğärif.

Vladykin, V. (1994): Religiozno-mifologicheskaia kartina mira udmurtov. Izhevsk, Udmurtia.

Zamaletdinov, L. (1979): O mifologicheskoi osnove skazki "Shüräle". In: Sadekova, A. (compiler): Gabdulla Tuqay. Materialy nauchnoi konferentsii i iubileinykh torzhestv, posviashchennykh 90-letiiu so dnia rozhdeniia poèta. Kazan, Tatarskoe Knizhnoe Izdatel'stvo. 